\title{
Isolation, identification and proving the pathogenicity of banana anthracnose pathogen Colletotrichum musae
}

\author{
RANI R. UNNITHAN* AND N. THAMMAIAH \\ College of Horticulture, Yalachahally Horticulture Farm, Yelwala, MYSORE (KARNATAKA) INDIA
}

\section{ARITCLE INFO}

Received : 25.07 .2017

Revised : 04.09 .2017

Accepted : 16.09 .2017

\section{KEY WORDS :}

Anthracnose, Banana, Colletotrichum musae

*Corresponding author:

\begin{abstract}
:
Colletotrichum musae was isolated from dark-brown anthracnose lesions on banana (Musa sp.) to establish the causal agent of the symptom. The fungus grew fast and producedpale red mycelial growth on PDA when incubated at $28{ }^{\circ} \mathrm{C}$ for 7 days. Conidia were aseptate, hyaline, mostly ellipsoid, ranging from 10-18 $\mu \mathrm{m}$ and 5-9 $\mu \mathrm{m}$ (average of 14.5-6.9 $\mu \mathrm{m}$ ). The isolates of $C$. musae caused black necrotic lesions on banana fruits byneedle-wound inoculation and orange-coloured sporemasses were produced on the lesions. The control fruits which were not inoculated with the fungus did not show any symptoms of the disease.
\end{abstract}

How to view point the article : Unnithan, Rani R. and Thammaiah, N. (2017). Isolation, identification and proving the pathogenicity of banana anthracnose pathogen Colletotrichum musae. Internat. J. Plant Protec., 10(2) : 399-403, DOI : 10.15740/HAS/IJPP/10.2/399-403. 